\title{
Influence of Ammonium Sulfate and Rotation Crops on Strawberry Black Root Rot
}

\author{
Wade H. Elmer, The Connecticut Agricultural Experiment Station, New Haven 06504; and James A. LaMondia, \\ The Connecticut Agricultural Experiment Station, Valley Laboratory, Windsor 06095
}

\begin{abstract}
Elmer, W. H., and LaMondia, J. A. 1999. Influence of ammonium sulfate and rotation crops on strawberry black root rot. Plant Dis. 83:119-123.

The combined effects of rotation crops and nitrogen fertilizers were examined on the strawberry black root rot disease complex. In July 1995, microplots were filled with soil that had a history of strawberry black root rot and seeded with two types of oats (Avena strigosa 'Saia oats' or A. sativa 'Garry oats') or with sorgho-sudangrass (Sorghum bicolor $\times$ S. sudanense 'Triple S'). Microplots planted with 1-year-old 'Honeoye' strawberry crowns served as the controls. In May 1996, the crops were chopped and incorporated into the soil. The soil was re-planted with 1year-old strawberry 'Honeoye' crowns and then fertilized with $\left(\mathrm{NH}_{4}\right)_{2} \mathrm{SO}_{4}$ or $\mathrm{Ca}\left(\mathrm{NO}_{3}\right)_{2}$ at equivalent rates of $\mathrm{N}$. Two months later, $\left(\mathrm{NH}_{4}\right)_{2} \mathrm{SO}_{4}$-treated plants had $36 \%$ more leaf area and $41 \%$ more runners than strawberries treated with $\mathrm{Ca}\left(\mathrm{NO}_{3}\right)_{2}$. Strawberries that had been precropped with 'Saia' oats had $135 \%$ more runners and $38 \%$ more early fruit yield than strawberries grown in control microplots. Total fruit yield was not affected by the treatments. Compared to $\mathrm{Ca}\left(\mathrm{NO}_{3}\right)_{2}$, the $\left(\mathrm{NH}_{4}\right)_{2} \mathrm{SO}_{4}$ treatment reduced the percentage of blackened roots. The influence of the cover crops on growth and disease was stronger with $\left(\mathrm{NH}_{4}\right)_{2} \mathrm{SO}_{4}$ fertilization than with $\mathrm{Ca}\left(\mathrm{NO}_{3}\right)_{2}$ fertilization. Combining 'Saia' oats or sorgho-sudangrass rotation with $\left(\mathrm{NH}_{4}\right)_{2} \mathrm{SO}_{4}$ fertilization reduced lesion nematode (Pratylenchus penetrans) numbers in subsequent strawberry roots when compared to controls. Also, the combination of 'Saia' or 'Garry' oats as a precrop with applications of $\left(\mathrm{NH}_{4}\right)_{2} \mathrm{SO}_{4}$ reduced black root rot severity when compared to controls. Only the 'Garry' oat rotation reduced strawberry root colonization by Rhizoctonia fragariae when compared to controls. Other effects were associated with using $\left(\mathrm{NH}_{4}\right)_{2} \mathrm{SO}_{4}$. The $\left(\mathrm{NH}_{4}\right)_{2} \mathrm{SO}_{4}$ treatment lowered the rhizosphere soil $\mathrm{pH}$ by 0.2 units, reduced the numbers of fluorescent pseudomonads in the rhizosphere by 10- to 15-fold, and produced leaves that had more $\mathrm{N}, \mathrm{K}, \mathrm{S}, \mathrm{Mn}$, and $\mathrm{Zn}$ content than plants treated with $\mathrm{Ca}\left(\mathrm{NO}_{3}\right)_{2}$. Rotation with 'Saia' oats combined with $\left(\mathrm{NH}_{4}\right)_{2} \mathrm{SO}_{4}$ fertilization may suppress strawberry black root rot and increase yields through multiple effects on the host, pathogens, and associated microflora.
\end{abstract}

Black root rot is a complex root disease of strawberry (Fragaria X ananassa Duchesne) which causes root death and reduces plant vigor, productivity, and winter survival $(4,13,15,26)$. Although many organisms are implicated in black root rot, surveys in Connecticut and elsewhere found that a binucleate Rhizoctonia sp. ( $R$. fragariae Hussain and McKeen; 13) in anastomosis groups AG-A, AG-G, and AG-I (16,17); lesion nematodes (Pratylenchus penetrans (Cobb) Filip. \& Shur. Stek) $(2,7,8,15,20,23,26)$; or both were consistently associated with the disease. Other minor fungi, such as Pythium, Iridella, Fusarium, and Cylindrocarpon

Corresponding author: Wade Elmer E-mail: Wade.Elmer@po.state.ct.us

This study was supported in part by USDA CSREES Northeast IPM Special Grant No. 9534103-1544 and by the North American Strawberry Growers Association.

Accepted for publication 12 October 1998.

Publication no. D-1998-1130-05R

(C) 1999 The American Phytopathological Society spp. (26), and certain rapidly growing gram-negative rod bacteria, have also been implicated in strawberry black root rot $(9,25)$.

Affected plants typically exhibit stunting and necrotic centers. Leaves are smaller and the number of runners are reduced. Affected roots can have blackened lesions that extend into the cortical tissue, leaving the stele white for a period of time. Lesions coalesce to blacken the whole root. Cultivars that are resistant to black root rot are not available. Pre-plant fumigation may suppress black root rot in the year of planting, but typically does not offer any lasting control. Current control recommendations are to avoid abiotic stresses, such as drought, winter injury, and heavy wet soils, and to use a two-year rotation with grains $(4,26)$.

In New England, straw is used as a winter mulch for strawberries, so rotation with grains has been readily adopted by many growers to produce straw. However, rotation crops can vary in their susceptibility as hosts to $R$. fragariae and $P$. penetrans (14). Past research has demonstrated that 'Saia' oats (Avena strigosa Schreb.) and 'Triple S' sorgho-sudangrass (Sorghum bicolor $\times S$. sudanense) were poor hosts of $R$. fragariae and $P$. penetrans, whereas 'Garry' oats (Avena sativa L), rye (Secale cereale L), buckwheat (Fagopyrum escultentum Moench), canola (Brassica napus L), or strawberries either increased or did not affect the population densities of the pathogens (14). Furthermore, Hildebrand and West $(9,25)$ found that strawberry black root rot was increased following particular rotation crops and was associated with elevated levels of fluorescing and nonfluorescing gram-negative rod bacteria in the rhizosphere of strawberry.

Another control method for suppressing black root rot may be through management of mineral nutrition. In field studies, fertilization with $\left(\mathrm{NH}_{4}\right)_{2} \mathrm{SO}_{4}$ suppressed strawberry black root rot and increased leaf area, number of runners, and berry yields more than fertilization with $\mathrm{Ca}\left(\mathrm{NO}_{3}\right)_{2}$ (6). Plants treated with $\left(\mathrm{NH}_{4}\right)_{2} \mathrm{SO}_{4}$ had more $\mathrm{N}$ and $\mathrm{Mn}$ in the leaves than $\mathrm{Ca}\left(\mathrm{NO}_{3}\right)_{2}$ treated plants. Increased $\mathrm{Mn}$ availability has been implicated in disease resistance (12); therefore, $\left(\mathrm{NH}_{4}\right)_{2} \mathrm{SO}_{4}$ may function in disease suppression by enhancing $\mathrm{Mn}$ uptake. Furthermore, Mn-transforming microorganisms may be associated with black root rot as in other root diseases (12). An oat pre-crop can increase the availability of $\mathrm{Mn}$ by affecting the number of Mn-oxidizing or Mn-reducing bacteria, or both, in soil (12).

A combination of disease-suppressive rotation crops and disease-suppressive fertilizers may provide greater disease suppression than either practice alone. Our objectives were to compare the combined and individual effects of the cover crops (oat cvs. Saia and Garry and sorgho-sudangrass) with nitrogen fertilizers $\left(\mathrm{NH}_{4}\right)_{2} \mathrm{SO}_{4}$ or $\mathrm{Ca}\left(\mathrm{NO}_{3}\right)_{2}$ on strawberry growth and nutrition, black root rot, and microbial changes in the rhizosphere.

\section{MATERIALS AND METHODS}

Plot establishment and fertilizer treatments. In July 1995, 48 microplots consisting of polyvinyl chloride tubes $(15-\mathrm{cm}$ in diameter and $0.46 \mathrm{~m}$ long) were set 0.3 $\mathrm{m}$ deep in Windsor, Connecticut and filled with soil (Watchaug fine sandy loam, $\mathrm{pH}$ 5.9) that previously had been planted with strawberries and where symptoms of black root rot had been severe. Twelve microplots were seeded with 10 to 15 seeds of oat cvs. Garry or Saia or sorgho-sudan- 
grass, and 12 microplots were planted with 1-year-old 'Honeoye' strawberry crowns (one per microplot) to serve as controls. Of the 12 microplots that were seeded with the grasses, 6 were fertilized with $\left(\mathrm{NH}_{4}\right)_{2} \mathrm{SO}_{4}$ at $50 \mathrm{~kg}$ of N/ha $(0.06 \mathrm{~g}$ of N/microplot $)$, and the other 6 were fertilized with $\mathrm{Ca}\left(\mathrm{NO}_{3}\right)_{2}$ at $50 \mathrm{~kg}$ of $\mathrm{N} / \mathrm{ha}$. Microplots planted with strawberries received $\mathrm{Ca}\left(\mathrm{NO}_{3}\right)_{2}$ or $\left(\mathrm{NH}_{4}\right)_{2} \mathrm{SO}_{4}$ at $112 \mathrm{~kg}$ of $\mathrm{N} / \mathrm{ha}$ ( $0.14 \mathrm{~g}$ of $\mathrm{N} /$ microplot). Phosphorous, $\mathrm{K}$, $\mathrm{Ca}, \mathrm{Mg}$, and $\mathrm{S}$ were applied to each plot at $45,45,30$, and $45 \mathrm{~kg} / \mathrm{ha}$, respectively. Fertilizers were dissolved in $50 \mathrm{ml}$ of water and poured on top of the soil. Therefore, eight treatments (three cover crops plus the control $\times$ two nitrogen fertilizers) were applied to 48 microplots in a complete randomized blocked factorial design (two blocks; three replicates per block). The experiment was repeated in Hamden, Connecticut 1 week later.

In May 1996, cover crop residues or surviving strawberry crowns were chopped and incorporated into the soil with trowels. Each plot was then planted with one 1year-old 'Honeoye' strawberry crown. Microplots that had been treated with $\mathrm{Ca}\left(\mathrm{NO}_{3}\right)_{2}$ or $\left(\mathrm{NH}_{4}\right)_{2} \mathrm{SO}_{4}$ in 1995 continued to receive the same nitrogen fertilizer in 1996. Each microplot received $85 \mathrm{~kg}$ of $\mathrm{N} / \mathrm{ha}(0.01 \mathrm{~g}$ of N/ microplot) at planting and $85 \mathrm{~kg}$ of N/ha in July 1996. All microplots received $\mathrm{K}, \mathrm{P}, \mathrm{Ca}$, and $\mathrm{S}$ at the total seasons equivalent of $84,84,30$, and $45 \mathrm{~kg} / \mathrm{ha}$, respectively. In May 1997, at $10 \%$ bloom, microplots received $10 \%$ of the total 1996 fertilizer rate. A total of $60 \%$ was applied at renovation on 25 July and the remaining $30 \%$ was applied on 9 September.

Sampling and measurements. In 1996, the treatment effects on black root rot and plant health were measured by counting the runners which were removed weekly in June and July and by measuring leaf area (A) in late June and late July. Leaf area was determined by the equation: $A=3.02+$ $1.77 L \times \mathrm{W}\left(R^{2}=0.98\right)$, in which $L$ and $W$ are the length and width, respectively, of the middle leaflet of each strawberry leaf. This equation was generated by regressing the products of the lengths and widths from 84 'Honeoye' strawberry leaves against their leaf areas, which were determined on a leaf area meter (Delta-T Devices, Pullman, WA). In June 1997, berries were picked, counted, and weighed for a total of eight harvest dates. Early fruit harvests are more economically important than later pickings, so early yield was measured and defined as the total harvest from the first four pickings. Runners were not removed during the 1997 growing season, which is conventional for strawberry culture. In September 1997, the microplots were removed from the surrounding soil and the plant with its roots and soil were removed from each microplot. Loose soil was gently dislodged from the roots, after which the roots were vigorously shaken into plastics bags to sample the rhizosphere soil. The soil was immediately stored on ice until it could be refrigerated at $4{ }^{\circ} \mathrm{C}$. Plant tops and roots were separated just below the junction where the petioles are attached to the crown. The roots and plant tops were washed in tap water to remove soil, blotted dry between absorbent paper towels, and weighed. The foliar portions were oven dried and weighed.

Root systems were rated for black root rot by estimating the percentage of blackened roots. Roots were sampled for isolation of the pathogens. From each root system, $1-\mathrm{cm}$ sections were cut from two young structural roots that emerged from the crown (crown roots), two blackened perennial roots that were devoid of feeder roots (main perennial roots), and two feeder roots. Root sections were washed in tap water, rinsed with distilled water, and placed on water agar. Plates were incubated for 5 days at room temperature and microscopically examined (200x magnification). Each root section was scored as being colonized by Rhizoctonia spp., Fusarium spp., Pythium spp., other fungi, or not colonized. Values were presented as percent root colonization. Lesion nematodes were extracted from roots by agitating $2 \mathrm{~g}$ of chopped roots ( 0.5 to $1 \mathrm{~cm}$ long) in water for 5 days, decanting the nematodes onto sieves, and counting the lesion nematodes under a microscope (1). Values were presented as number of lesion nematodes per $\mathrm{g}$ root.

Rhizosphere soil was serially diluted into sterile normal saline blanks. Aliquots $(0.1 \mathrm{ml})$ of each dilution were spread onto $10 \%$ tryptic-soy agar plus $13.5 \mathrm{~g} /$ liter agar (Difco Laboratories, Inc., Detroit) in 10cm-diameter petri plates to enumerate aerobic heterotrophic bacteria, King's B agar for fluorescent pseudomonads, and Mn-dioxide agar (5 $\mathrm{g}$ of Mn-dioxide, $30 \mathrm{~g}$ of sucrose, $1 \mathrm{~g}$ of Difco yeast extract, $15 \mathrm{~g}$ of agar) for Mn-reducing bacteria. Three plates of each media per dilution were prepared and incubated in the dark for 2 to 3 days at $25^{\circ} \mathrm{C}$. Soil moisture was determined independently. For total bacteria, $10 \%$ tryptic-soy agar plates that contained between 30 and 300 colonies were counted, averaged over the three plates, and expressed as log colonies of bacteria/g soil (oven dry weight equivalent). Fluorescent pseudomonads were enumerated by viewing King's B agar under shortwave UV light 2 days later. Mn-reducing bacteria were detected 2 weeks later on $\mathrm{Mn}$ dioxide agar by the zones of clearing that appeared around the colony. Fluorescent pseudomonads and Mn-reducers were expressed as log densities/g soil (oven dry weight equivalent).

Tissue analyses. The leaf samples collected in 1996 were dried to constant weights at $50^{\circ} \mathrm{C}$ and ground to powder in a mortar with a pestle. Dried tissue (1 g) from the three replicate plants in one block were bulked, and $1 \mathrm{~g}$ of dried tissue from three plants in the other block were bulked. Dried tissue $(0.5 \mathrm{~g})$ from these two bulked samples was digested with $5 \mathrm{ml}$ of $\mathrm{HCl}$ and $10 \mathrm{ml}$ of $\mathrm{HNO}_{3}$ in a CEM MDS 81D microwave (CEM Co. Matthews, NC). Samples were brought up to $50 \mathrm{ml}$ with deionized water. The elements $\mathrm{K}, \mathrm{P}, \mathrm{Ca}, \mathrm{Mg}, \mathrm{S}$, $\mathrm{Fe}, \mathrm{Mn}, \mathrm{Zn}, \mathrm{Cu}$, and $\mathrm{B}$ were quantified by plasma spectrophometry on a Thermo Jarrell Atom Scan spectrophotometer and expressed as $\mu \mathrm{mol} / \mathrm{g}$ dry weight. Nitrogen was determined using the Kjeldahl procedure. Leaf tissue $(0.25 \mathrm{~g})$ from the two bulked samples were heated and digested in $4 \mathrm{ml}$ of $\mathrm{H}_{2} \mathrm{SO}_{4}$ and $10 \mathrm{ml}$ of $\mathrm{H}_{2} \mathrm{O}_{2}$ and analyzed colorimetrically for total N. Values were averaged and presented as $\mu \mathrm{mol} / \mathrm{g}$ dry weight.

Statistical procedures. Data were subjected to analysis of variance for a blocked factorial design. Since there were no significant interactions between the treatments and the Hamden site or with the Windsor site at $P=0.05$, values from both sites were combined for analysis and presentation. Mean separation was done using the Student-Newman-Keul Test at $P=$ 0.05 .

\section{RESULTS}

Differences in leaf area were found in July 1996 (Table 1), but not in June (data not shown). Plants fertilized with $\left(\mathrm{NH}_{4}\right)_{2} \mathrm{SO}_{4}$ had $36 \%$ more leaf area $(P=$ $0.02)$ and $41 \%$ more runners $(P=0.02)$ than plants treated with $\mathrm{Ca}\left(\mathrm{NO}_{3}\right)_{2}$. Precropping with 'Saia' oats led to a $135 \%$ increase in runners $(P=0.04)$ when compared to continuous strawberry culture. In June 1997, early berry yields were greater from plants pre-cropped with Saia oats than controls $(P=0.04)$. Total yield was not significantly affected, but the trends reflected the same pattern observed with the early yield. The nitrogen fertilizers did not affect yield. In September 1997, the fresh weights of roots of the strawberry plants pre-cropped with Saia oats and treated with $\left(\mathrm{NH}_{4}\right)_{2} \mathrm{SO}_{4}$ were larger than any other treatment combination $(P=$ $0.05)$. In addition, fertilization with $\left(\mathrm{NH}_{4}\right)_{2} \mathrm{SO}_{4}$ produced plants that were $17 \%$ larger than those fertilized with $\mathrm{Ca}\left(\mathrm{NO}_{3}\right)_{2}$ $(P=0.05)$ Pre-cropping the soil with Saia oats produced strawberry plants that had more dry weight than controls $(P<0.001)$. We calculated a fresh root weight to fresh top weight ratio to assess the treatment effects on distribution of plant weight. Treatment with $\mathrm{Ca}\left(\mathrm{NO}_{3}\right)_{2}$ yielded plants with root systems that weighed proportionately less than their tops when compared to plants fertilized with $\left(\mathrm{NH}_{4}\right)_{2} \mathrm{SO}_{4}(P=$ 0.05).

There was an significant interaction between the two oat cover crops and $\left(\mathrm{NH}_{4}\right)_{2} \mathrm{SO}_{4}$ fertilization in reducing the percentage of blackened roots when com- 
pared to other treatments $(P=0.01$; Table $2)$. There were also fewer blackened roots on plants treated with $\left(\mathrm{NH}_{4}\right)_{2} \mathrm{SO}_{4}$ when compared to $\mathrm{Ca}\left(\mathrm{NO}_{3}\right)_{2}(P=0.01)$. Rhizoctonia spp. were isolated from the strawberry roots $68 \%$ of the time, whereas Fusarium and Pythium spp. were detected only 7.4 and $0.8 \%$ of the time, respectively (data not shown). Of the three classes of roots, the perennial main roots were most colonized by Rhizoctonia spp., followed by feeder roots and then crown roots. Plants pre-cropped with 'Garry' oats had less colonization of feeder roots and main perennial roots by Rhizoctonia spp. than roots from the control treatment $(P=$ $0.05)$. The roots of strawberries that were pre-cropped with Saia oats or with sorghosudangrass and then treated with $\left(\mathrm{NH}_{4}\right)_{2} \mathrm{SO}_{4}$ had 66 or $51 \%$ fewer nematodes, respectively, than controls treated with $\left(\mathrm{NH}_{4}\right)_{2} \mathrm{SO}_{4} \quad(P=0.001)$. Lesion nematode numbers did not differ between strawberries that were pre-copped with Garry oats and control strawberries. Lesion nematodes were recovered in greater densities from roots treated with $\left(\mathrm{NH}_{4}\right)_{2} \mathrm{SO}_{4}$ than with $\mathrm{Ca}\left(\mathrm{NO}_{3}\right)_{2}(P=0.001)$.

The rhizosphere $\mathrm{pH}$ in soil treated with $\left(\mathrm{NH}_{4}\right)_{2} \mathrm{SO}_{4}$ was 4.81 , compared to 5.08 for $\mathrm{Ca}\left(\mathrm{NO}_{3}\right)_{2}(P=0.001)$, but there were no differences between the cover crops (Table $3)$. The rhizosphere soil of $\left(\mathrm{NH}_{4}\right)_{2} \mathrm{SO}_{4}$ treated plants had a 10 - to 15 -fold reduction in the number of fluorescent pseudomonads when compared to $\mathrm{Ca}\left(\mathrm{NO}_{3}\right)_{2}-$ treated rhizosphere soil $(P<0.001)$. Total heterotrophic bacteria and Mn-reducing microbes were not affected by the treatments.

The mineral composition of the strawberry leaves sampled in September 1996 did not significantly differ between the two sites except for the elements $\mathrm{N}, \mathrm{K}, \mathrm{Mg}$, and $\mathrm{S}$, which were in greater concentration in Windsor than in Hamden. Since there were no interactions between site and treatments, values from both sites were combined for analysis and presentation (Table 4). Leaf concentrations of N, K, S, and $\mathrm{Zn}$ in plants treated with $\left(\mathrm{NH}_{4}\right)_{2} \mathrm{SO}_{4}$ were significantly increased by 7 to $30 \%$, while Mn levels were significantly increased by $103 \%$ compared to those fertilized with $\mathrm{Ca}\left(\mathrm{NO}_{3}\right)_{2}$. Sorgho-sudangrass and both oat species increased the leaf concentration of $\mathrm{Ca}$ and $\mathrm{Mg}$ when compared to controls plants.

\section{DISCUSSION}

Combining Saia oats as a single season rotation with $\left(\mathrm{NH}_{4}\right)_{2} \mathrm{SO}_{4}$ fertilization produced larger strawberry plants, more early yield, and less damage from black root rot than if Saia oats were combined with $\mathrm{Ca}\left(\mathrm{NO}_{3}\right)_{2}$ or if another rotation crop was combined with the $\left(\mathrm{NH}_{4}\right)_{2} \mathrm{SO}_{4}$ treatment. Rotating strawberry with sorgho-sudangrass and fertilizing with $\left(\mathrm{NH}_{4}\right)_{2} \mathrm{SO}_{4}$ reduced lesion nematodes but did not affect disease severity or yield. Similarly, Garry oats reduced disease severity and root colonization by $R$. fragariae but did not increase plant growth or yield. Huber and McCay-Buis (11) cited both pre-cropping

Table 1. Growth and yield components of strawberry plants grown in microplots infested with the black root rot pathogens that had been pre-cropped with cover crops and fertilized with $\left(\mathrm{NH}_{4}\right)_{2} \mathrm{SO}_{4}$ or $\mathrm{Ca}\left(\mathrm{NO}_{3}\right)_{2}$

\begin{tabular}{|c|c|c|c|c|c|c|c|}
\hline \multirow[b]{2}{*}{ Previous cover crop } & \multirow[b]{2}{*}{1996 leaf area $\left(\mathrm{cm}^{2}\right)$} & \multirow[b]{2}{*}{1996 runners } & \multicolumn{5}{|c|}{1997} \\
\hline & & & $\begin{array}{c}\text { Early berry } \\
\text { yield (g/plant) }\end{array}$ & $\begin{array}{c}\text { Total berry } \\
\text { yield (g/plant) }\end{array}$ & $\begin{array}{l}\text { Fresh root } \\
\text { weight (g) }\end{array}$ & $\begin{array}{l}\text { Dry foliar } \\
\text { weight (g) }\end{array}$ & $\begin{array}{l}\text { Fresh root/ } \\
\text { shoot ratio }\end{array}$ \\
\hline \multicolumn{8}{|l|}{$\left(\mathrm{NH}_{4}\right)_{2} \mathrm{SO}_{4}$} \\
\hline Garry oats & 543 & $8.8 \mathrm{ab}$ & $68.8 \mathrm{bc}$ & 112.1 & $34.3 \mathrm{a}$ & $12.1 \mathrm{ab}$ & 0.97 \\
\hline Saia oats & 746 & $12.2 \mathrm{c}$ & $79.5 \mathrm{~cd}$ & 121.9 & $44.5 \mathrm{~b}$ & $16.8 \mathrm{~b}$ & 0.96 \\
\hline SS-grass & 668 & $11.8 \mathrm{bc}$ & $63.9 \mathrm{ab}$ & 98.0 & $26.9 \mathrm{a}$ & $10.5 \mathrm{a}$ & 0.92 \\
\hline Mean & $590^{*}$ & $10.0^{*}$ & 66.8 & 102.0 & $33.9 *$ & 13.1 & $0.95 *$ \\
\hline \multicolumn{8}{|l|}{$\mathrm{Ca}\left(\mathrm{NO}_{3}\right)_{2}$} \\
\hline Strawberry & 316 & $3.0 \mathrm{a}$ & $61.8 \mathrm{ab}$ & 66.5 & $32.0 \mathrm{a}$ & $10.9 \mathrm{a}$ & 0.89 \\
\hline Garry oats & 385 & $7.0 \mathrm{ab}$ & $51.2 \mathrm{a}$ & 60.8 & $29.1 \mathrm{a}$ & $9.6 \mathrm{a}$ & 0.97 \\
\hline Saia oats & 641 & $11.5 \mathrm{~b}$ & $81.6 \mathrm{~d}$ & 148.5 & $27.7 \mathrm{a}$ & $16.0 \mathrm{~b}$ & 0.64 \\
\hline SS grass & 390 & $7.0 \mathrm{ab}$ & $56.8 \mathrm{a}$ & 49.6 & $27.2 \mathrm{a}$ & $12.1 \mathrm{ab}$ & 0.79 \\
\hline Mean & 433 & 7.1 & 62.9 & 86.2 & 29.0 & 11.4 & 0.82 \\
\hline
\end{tabular}

y Early yield refers to the first four harvests.

${ }^{\mathrm{z}}$ Values followed by an asterisk ( $\mathrm{N}$-form) or differing letters (cover crops) are significantly different from their respective controls according to StudentNewman-Kuel's tests $(P=0.05)$.

Table 2. Percentage of blackened roots and recovery of Rhizoctonia fragariae and lesion nematodes (Pratylenchus penetrans) from strawberry roots and of plants grown in microplots infested with the black root rot pathogens, pre-cropped with cover crops, and fertilized with $\left(\mathrm{NH}_{4}\right)_{2} \mathrm{SO}_{4}$ or Ca( $\left(\mathrm{NO}_{3}\right)_{2}$

\begin{tabular}{|c|c|c|c|c|c|}
\hline \multirow[b]{2}{*}{ Cover crop } & \multirow[b]{2}{*}{$\%$ Blackened roots } & \multicolumn{3}{|c|}{ \% roots colonized by Rhizoctonia sp. } & \multirow[b]{2}{*}{ Nematodes/g feeder root } \\
\hline & & Feeder roots & Main perennial roots & New crown roots & \\
\hline $\begin{array}{l}\left(\mathrm{NH}_{4}\right)_{2} \mathrm{SO}_{4} \\
\text { Strawberry } \\
\text { Garry oats } \\
\text { Saia oats } \\
\text { Sorgho-sudangrass }\end{array}$ & $\begin{array}{l}59.0 \mathrm{a}^{\mathrm{y}} \\
30.0 \mathrm{~b} \\
31.6 \mathrm{~b} \\
41.6 \mathrm{ab}\end{array}$ & $\begin{array}{l}78 \mathrm{a}^{\mathrm{z}} \\
59 \mathrm{ab} \\
71 \mathrm{a} \\
73 \mathrm{a}\end{array}$ & $\begin{array}{l}85 \mathrm{a}^{\mathrm{z}} \\
59 \mathrm{~b} \\
71 \mathrm{ab} \\
86 \mathrm{a}\end{array}$ & $\begin{array}{l}71 \mathrm{a}^{\mathrm{z}} \\
71 \mathrm{a} \\
58 \mathrm{ab} \\
45 \mathrm{~b}\end{array}$ & $\begin{array}{l}352.5 \mathrm{a}^{\mathrm{y}} \\
386.0 \mathrm{a} \\
120.0 \mathrm{c} \\
179.8 \mathrm{~b}\end{array}$ \\
\hline Mean & $40.6^{*}$ & 70 & 75 & 61 & $261.3 *$ \\
\hline $\begin{array}{l}\mathrm{Ca}\left(\mathrm{NO}_{3}\right)_{2} \\
\text { Strawberry } \\
\text { Garry oats } \\
\text { Saia oats } \\
\text { Sorgho-sudangrass }\end{array}$ & $\begin{array}{l}47.5 \mathrm{ab} \\
50.0 \mathrm{ab} \\
47.2 \mathrm{ab} \\
57.5 \mathrm{a}\end{array}$ & $\begin{array}{l}78 \mathrm{a} \\
44 \mathrm{~b} \\
75 \mathrm{a} \\
65 \mathrm{ab}\end{array}$ & $\begin{array}{l}86 a \\
55 \mathrm{~b} \\
75 \mathrm{ab} \\
75 \mathrm{ab}\end{array}$ & $\begin{array}{l}64 a b \\
44 b \\
75 a \\
70 a\end{array}$ & $\begin{array}{r}105.0 \mathrm{c} \\
131.1 \mathrm{c} \\
100.8 \mathrm{c} \\
92.5 \mathrm{c}\end{array}$ \\
\hline Mean & 50.6 & 66 & 73 & 63 & 107.4 \\
\hline
\end{tabular}

y Values represent means of 12 replicates plants; values followed by an asterisk ( $\mathrm{N}$-form) or differing letters (cover crops) are significantly different from respective controls according to Student-Newman-Kuel's test $(P=0.05)$.

${ }^{\mathrm{z}}$ Values represent the means of 12 replicates plants (two root pieces per plant); values followed by an asterisk (N-form) or differing letters (cover crop) are significantly different from respective controls according to Student-Newman-Kuel's test $(P=0.05)$. 
with oats and fertilizing with $\mathrm{NH}_{4}-\mathrm{N}$ as being suppressive to take-all of wheat. Our findings support the hypothesis that combining rotation with oats with $\mathrm{NH}_{4}-\mathrm{N}$ fertilization can reduce root diseases in plants.

Both oat cultivars suppressed black root rot under the $\left(\mathrm{NH}_{4}\right)_{2} \mathrm{SO}_{4}$ regime but differed in their effect on the two main pathogens. Saia oats reduced the number of root lesion nematodes but did not affect root colonization by Rhizoctonia spp. Garry oats reduced root colonization by Rhizoctonia spp. but did not affect the numbers of lesion nematodes. Furthermore, the Saia oat pre-crop increased early berry yield but Garry oats had no effect. The early yield increase following rotation with Saia oats may have been due to its unsuitability as a host for the lesion nematode which, in these soils, may have been a more yieldreducing pathogen. In other experiments, we have found that Saia oats were similar in effect to Garry oats in reducing $R$. fragariae recovery from soil $(14 ; \mathrm{J}$. A. LaMondia, unpublished research). Therefore, the failure of Garry oats to affect yield may have been its high susceptibility to the lesion nematode. The resistance of Saia oats to the lesion nematode was first recognized by Colbran (3), who found that it was useful in suppressing the re-plant problem in apple orchards. Townsend (24) later showed that Saia oats were resistant to Pratylenchus neglectus Rensch and $P$. penetrans. However, the resistance to lesion nematode does not completely explain the effect of Saia oats on disease and yield because sorgho-sudangrass also reduced the number of lesion nematodes but had no significant effect on disease severity or yield. It is possible the reduction in nematode densities by sorgho-sudangrass was insufficient to have an effect on yield. It is also possible that oat straw residues may have specific effects on the disease. Papavizas (18) reported that oat (presumably A. sativa) straw residues increased the number of antagonistic bacteria to $R$. solani and to other fungal pathogens in soil. Since we did not examine antagonism, it is unclear whether or not the residues of Avena spp. act differently toward soil microbes than those of sorgho-sudangrass.

The association of Rhizoctonia spp. with strawberry roots extends from being mycorrhizal to being pathogenic (19). Past studies with this same soil type found nearly all isolates of Rhizoctonia from strawberry roots were members of the virulent anastomosis groups, AG-A, AG$\mathrm{G}$, and AG-I of binucleate $R$. fragariae (17). The very low frequency of isolating Pythium or Fusarium spp. suggests that, in these soils, they were not a significant factor in the black root rot complex.

Fertilization with $\left(\mathrm{NH}_{4}\right)_{2} \mathrm{SO}_{4}$ led to more disease suppression and more plant growth than with $\mathrm{Ca}\left(\mathrm{NO}_{3}\right)_{2}$, but yield was not affected. In past studies, $\left(\mathrm{NH}_{4}\right)_{2} \mathrm{SO}_{4}$ reduced black root rot and increased yield in strawberry (6) and suppressed root diseases on other crops $(5,10,11)$. Fertilization with $\left(\mathrm{NH}_{4}\right)_{2} \mathrm{SO}_{4}$ did not affect the recovery of Rhizoctonia spp. from roots but did increase root weight and the number of lesion nematodes. Because $P$. penetrans is an obligate parasite and must live in living roots, it may not be unreasonable to find lower densities of this pathogen on roots of dead and declining strawberries, as evidenced in the $\mathrm{Ca}\left(\mathrm{NO}_{3}\right)_{2}$-treated plants, than on larger, healthier $\left(\mathrm{NH}_{4}\right)_{2} \mathrm{SO}_{4}$-treated plants.

The increase in mineral composition in $\left(\mathrm{NH}_{4}\right)_{2} \mathrm{SO}_{4}$-treated plants compared to $\mathrm{Ca}\left(\mathrm{NO}_{3}\right)_{2}$-treated plants has been observed before $(5,6)$. The doubling of the Mn con-

Table 3. Rhizosphere $\mathrm{pH}$, total bacteria, fluorescent pseudomonads, and Mn-reducing bacteria associated with strawberry roots grown in microplots infested with the black root rot pathogens, pre-cropped with different cover crops, and fertilized with $\left(\mathrm{NH}_{4}\right)_{2} \mathrm{SO}_{4}$ or $\mathrm{Ca}\left(\mathrm{NO}_{3}\right)_{2}$

\begin{tabular}{|c|c|c|c|c|}
\hline \multirow[b]{2}{*}{ Cover crop } & \multirow[b]{2}{*}{ Rhizosphere pH } & \multicolumn{3}{|c|}{ Log CFU/g soil } \\
\hline & & Fluorescent pseudomonads & Total bacteria & Mn-reducing bacteria \\
\hline \multicolumn{5}{|l|}{$\left(\mathrm{NH}_{4}\right)_{2} \mathrm{SO}_{4}$} \\
\hline Strawberry & 4.89 & 4.64 & 7.63 & 3.55 \\
\hline Garry oats & 4.77 & 4.55 & 7.38 & 3.75 \\
\hline Saia oats & 4.72 & 4.96 & 7.47 & 3.19 \\
\hline Sorgho-sudangrass & 4.85 & 5.02 & 7.26 & 3.41 \\
\hline Mean & $4.81 * \mathrm{z}$ & $4.79 *$ & 7.44 & 3.49 \\
\hline \multicolumn{5}{|l|}{$\mathrm{Ca}\left(\mathrm{NO}_{3}\right)_{2}$} \\
\hline Strawberry & 4.96 & 5.79 & 7.19 & 3.48 \\
\hline Garry oats & 5.19 & 5.90 & 7.56 & 3.43 \\
\hline Saia oats & 5.22 & 5.85 & 7.44 & 3.85 \\
\hline Sorgho-sudangrass & 4.94 & 6.12 & 7.14 & 3.87 \\
\hline Mean & 5.08 & 5.91 & 7.33 & 3.65 \\
\hline
\end{tabular}

z Values represent the means of 12 replicates plants; mean values followed by an asterisk are significantly different according to Student-Newman-Kuel's test $(P=0.05)$.

Table 4. Mineral composition of strawberry leaves grown in microplots infested with the black root rot pathogens, pre-cropped with cover crops, and fertilized with $\left(\mathrm{NH}_{4}\right)_{2} \mathrm{SO}_{4}$ or $\mathrm{Ca}\left(\mathrm{NO}_{3}\right)_{2}$

\begin{tabular}{|c|c|c|c|c|c|c|c|c|}
\hline \multirow[b]{2}{*}{ Cover crop } & \multicolumn{8}{|c|}{$\mu \mathrm{mol} / \mathrm{g}$ tissue } \\
\hline & $\mathbf{N}$ & $\mathbf{P}$ & $\mathbf{K}$ & $\mathrm{Ca}$ & Mg & $\mathbf{S}$ & Mn & Zn \\
\hline $\begin{array}{l}\left(\mathrm{NH}_{4}\right)_{2} \mathrm{SO}_{4} \\
\text { Strawberry } \\
\text { Garry oats } \\
\text { Saia oats } \\
\text { Sorgho-sudangrass }\end{array}$ & $\begin{array}{l}1,407 \\
1,357 \\
1,102 \\
1,272\end{array}$ & $\begin{array}{r}99 \\
90 \\
106 \\
102\end{array}$ & $\begin{array}{l}397 \\
334 \\
376 \\
367\end{array}$ & $\begin{array}{l}170 a \\
219 c \\
197 b c \\
227 c\end{array}$ & $\begin{array}{l}112 \mathrm{a} \\
118 \mathrm{a} \\
127 \mathrm{ab} \\
137 \mathrm{~b}\end{array}$ & $\begin{array}{l}44.0 \\
47.6 \\
44.9 \\
46.2\end{array}$ & $\begin{array}{l}6.5 \\
4.4 \\
5.1 \\
6.9\end{array}$ & $\begin{array}{l}0.56 \\
0.39 \\
0.40 \\
0.42\end{array}$ \\
\hline Mean & $1,285^{* z}$ & $99 *$ & $369^{*}$ & 203 & 123 & $45.7 *$ & $5.7 *$ & $0.44 *$ \\
\hline $\begin{array}{l}\mathrm{Ca}\left(\mathrm{NO}_{3}\right)_{2} \\
\text { Strawberry } \\
\text { Garry oats } \\
\text { Saia oats } \\
\text { Sorgho-sudangrass }\end{array}$ & $\begin{array}{r}978 \\
1,138 \\
1,107 \\
1,188\end{array}$ & $\begin{array}{l}107 \\
104 \\
102 \\
117\end{array}$ & $\begin{array}{l}349 \\
349 \\
323 \\
358\end{array}$ & $\begin{array}{l}158 \mathrm{a} \\
183 \mathrm{ab} \\
223 \mathrm{c} \\
203 \mathrm{bc}\end{array}$ & $\begin{array}{l}108 \mathrm{a} \\
134 \mathrm{~b} \\
135 \mathrm{~b} \\
131 \mathrm{~b}\end{array}$ & $\begin{array}{l}37.7 \\
41.0 \\
43.0 \\
41.0\end{array}$ & $\begin{array}{l}1.9 \\
2.1 \\
2.8 \\
4.2\end{array}$ & $\begin{array}{l}0.35 \\
0.34 \\
0.37 \\
0.36\end{array}$ \\
\hline Mean & 1,103 & 108 & 345 & 192 & 127 & 40.7 & 2.8 & 0.34 \\
\hline
\end{tabular}

z Values represent the means of four replicates each comprising three plants; values followed by an asterisk (N-form) or differing letters (cover crops) are significantly different from respective controls according to Student-Newman-Kuel's test $(P=0.05)$. 
tent, however, was striking. Manganese may be associated with disease suppression in strawberry (6) and other plants $(5,10,11,22)$. Manganese may increase synthesis of host defense products, reduce the virulence of the pathogens, and affect the biological suppression of the pathogen $(11,12,22)$. We hypothesized that the oat cultivars might increase availability of $\mathrm{Mn}$ via microbial transformations. However, we found no detectable effect between any of the rotation crops on Mn-reducing organisms. The acidification of the rhizosphere in $\left(\mathrm{NH}_{4}\right)_{2} \mathrm{SO}_{4}$-treated plants probably played a major role in increasing $\mathrm{Mn}$ availability. The putative role of $\mathrm{Mn}$ in disease needs to be deciphered.

Hildebrand and West $(9,25)$ found that diseased strawberry roots were associated with rapidly growing fluorescent and nonfluorescent gram-negative groups of bacteria. However, when black root rot was suppressed by rotation, they found that these bacterial groups were replaced by slow-growing bacteria (25). We found no effect of cover crops on microbial densities in the rhizosphere, but we observed that the fast-growing fluorescent pseudomonads were 10 to 15 times more abundant in the rhizosphere of the more diseased $\mathrm{Ca}\left(\mathrm{NO}_{3}\right)_{2}$-treated plants than in the rhizosphere of plants treated with $\left(\mathrm{NH}_{4}\right)_{2} \mathrm{SO}_{4}$. The role of these bacteria in black root rot is unclear. Pseudomonads are common exploiters of the rhizosphere and root and can be associated with root damage (21). Future investigations should determine if these bacteria are involved with black root rot and how fertilization affects their proliferation in the rhizosphere.

\section{ACKNOWLEDGMENTS}

We thank E. O'Dowd, J. Morrison, and D. Gaskill, for technical assistance; E. Naughton, R. Horvath, J. Rich, and M. Amore for assistance in field preparation and maintenance; and Nourse Farms, Inc., South Deerfield, Massachusetts for their donation of strawberry crowns.

\section{LITERATURE CITED}

1. Barker, K. R. 1985. Nematode extraction and bioassays. Pages 19-35 in: An Advanced Treatise on Meloidogyne, Vol. 2, Methodology. K. R. Barker, C. C. Carter, and J. N. Sasser, eds., N. C. State Univ. Graphics, Raleigh.

2. Chen, T. A., and Rich, A. E. 1962. The role of Pratylenchus penetrans in the development of strawberry black root rot. Plant Dis. Rep. 46:839-843.

3. Colbran, R. C. 1979. Problems in tree replacement. III. The effects of cultural practices and soil fumigation on root lesion nematodes and on the growth of apple replants. Aust. J. Agric. Res. 30:113-123.

4. Cooley, D. R., and Schloemann, S. G. 1994. Integrated pest management for strawberries in the northeastern United States. Univ. Mass. Coop. Ext. Syst. Amherst.

5. Elmer, W. H., and Ferrandino, F. J. 1994. Comparison of ammonium sulfate and calcium nitrate fertilization effects on Verticillium wilt of eggplant. Plant Dis. 78:811-816.

6. Elmer, W. H., and LaMondia, J. A. 1995. Influence of mineral nutrition on strawberry black root rot. Adv. Strawberry Res. 14:4248.

7. Goheen, A. C., and Bailey, J. S. 1955. Meadow nematodes in strawberry plantings in Massachusetts. Plant Dis. Rep. 39:879-880.

8. Goheen, A. C., and Smith, J. B. 1956. Effects of inoculation of strawberry roots with meadow nematodes, Pratylenchus penetrans. Plant Dis. Rep. 40:146-149.

9. Hildebrand, A. A., and West, P. M. 1941. Strawberry root rot in relation to microbiological changes induced in root rot soil by the incorporation of certain cover crops. Can J. Res. Sect. C 19:183-198.

10. Huber, D. M. 1989. The role of nutrition in the take-all disease of wheat and other small grains. Pages 46-74 in: Soilborne Plant Pathogens: Management of Diseases with Macro- and Microelements. A. Englehard, ed., APS Press, Inc., St. Paul, MN.

11. Huber, D. M., and McCay-Buis, T. S. 1993. A multiple component analysis of the take-all disease of cereal. Plant Dis. 77:437-447.

12. Huber, D. M., and Wilhelm, N. S. 1988. The role of manganese in resistance to plant disease. Pages 155-173 in: Manganese in Soils and Plants, R. D. Graham, R. J. Hannam, and N. C. Uren, eds., Kluwer Academic Publishers, Dordrecht, The Netherlands.

13. Hussain, S. S., and McKeen, W. E. 1963.
Rhizoctonia fragariae species nov. in relation to strawberry degeneration in Southwestern Ontario. Phytopathology 53:532-540.

14. LaMondia, J. A. 1994. The effect of rotation crops on strawberry black root rot pathogens in field microplots. J. Nematol. 26:108.

15. LaMondia, J. A., and Martin, S. B. 1989. The influence of Pratylenchus penetrans and temperature on black root rot of strawberry by binucleate Rhizoctonia species. Plant Dis. 73:107-110.

16. Martin, S. B. 1988. Identification, isolation frequency, and pathogenicity of anastomosis groups of binucleate Rhizoctonia species from strawberry roots. Phytopathology 78:379-384.

17. Ogoshi, A., Oniki, M., Sakair, R., and Vi, T. 1979. Anastomosis grouping among isolates of binucleate Rhizoctonia. Trans. Mycol. Soc. Jpn. 20:33-39.

18. Papavizas, G. C. 1963. Microbial antagonists in bean rhizosphere as affected by oat straw and supplemental nitrogen. Phytopathology 53:1430-1435.

19. Ribeiro, O. K., and Black, L. L. 1971. Rhizoctonia fragariae: a mycorrhizal and pathogenic fungus of strawberry plants. Plant Dis. Rep. 55:599-603.

20. Riggs, R. D., Slack, D. A., and Fulton, J. P. 1956. Meadow nematodes and its relation to decline of strawberry plants in Arkansas. (Abstr.) Phytopathology 46:24.

21. Schippers, B., Bakker, A. W., and Bakker, P. A. H. M. 1987. Interaction of deleterious and beneficial rhizosphere microorganisms and the effect of cropping practices. Annu. Rev. Phytopathol. 25:339-358.

22. Shoa, F. M., and Foy, C. D. 1982. Interaction of soil manganese and reaction of cotton to Verticillium wilt and Rhizoctonia root rot Comm. Soil. Soc. Plant Anal. 13:21-38.

23. Townsend, J. L. 1963. The pathogenicity of Pratylenchus penetrans to strawberry. Can. J. Plant Sci. 43:75-78

24. Townsend, J. L., 1989. Population densities of four species of root-lesion nematodes (Pratylenchus) in the oats cultivar Saia and OAC Woodstock. Can. J. Plant Sci. 69:903-905.

25. West, P. M., and Hildebrand, A. A. 1941. The microbiological balance of strawberry root rot soil as related to the rhizosphere and decomposition effects of certain cover crops. Can J. Res. Sect. C 19:199-210.

26. Wing, K. B., Pritts, M. P., and Wilcox, W. F. 1994. Strawberry black root rot: A review. Adv. Strawberry Res. 13:13-19. 